\title{
Evaluation of degree of conversion, microtensile bond strength and mechanical properties of three etch-and-rinse dental adhesives
}

\author{
Samantha Ariadne Alves de Freitas ${ }^{1}$, Marco Daniel Septimo Lanza², Karina Kato Carneiro ${ }^{3}$, \\ Alessandro Dourado Loguercio ${ }^{4}$ and José Bauer ${ }^{1 *}$
}

'Disciplina de Materiais Dentários, Curso de Odontologia, Universidade Federal do Maranhão - UFMA,
São Luís, MA, Brazil

${ }^{2}$ Departamento de Dentística Restauradora, Faculdade de Odontologia, Universidade Federal de Minas Gerais - UFMG, Belo Horizonte, MG, Brazil

${ }^{3}$ Curso de Odontologia, Departamento de Dentística Restauradora, Universidade Ceuma - Uniceuma, São Luís, MA, Brazil

${ }^{4}$ Departamento de Dentística Restauradora, Faculdade de Odontologia, Universidade Estadual de Ponta Grossa - UEPG, Ponta Grossa, PR, Brazil

*bauer@ufma.br

\begin{abstract}
This study evaluated microtensile bond strength ( $\mu$ TBS), degree of conversion, modulus of elasticity and ultramicrohardness of three etch-and-rinse adhesives systems. The materials evaluated were: Ambar (FGM), Optibond (Kerr) and Magic Bond (Vigodent). The degree of conversion was analyzed by FTIR/ATR. To evaluate bond strength ( $\mu$ TBS) in dentin, 15 teeth $(n=5)$ were restored and sliced to obtain the specimens $\left(0.8 \mathrm{~mm}^{2}\right)$. The dynamic ultra microhardness tester was used to evaluate the hardness and modulus of elasticity. The Magic Bond adhesive system showed lower $\mu$ TBS than Ambar and Optibond $(\mathrm{p}<0.001)$. For degree of conversion, comparisons between groups of adhesive systems evaluated showed statistically significant difference $(\mathrm{p}<0.001)$, with higher values for Ambar and Optibond when compared a Magic Bond. For modulus of elasticity and ultramicrohardness, Ambar and Magic Bond showed lower values than Optibond. The best results in all properties evaluated were obtained by the Optibond adhesive system.
\end{abstract}

Keywords: dental materials, adhesive, mechanical properties, microtensile bond strength, degree conversion.

\section{Introduction}

Based on the management of the smear layer substrate contemporary adhesive systems are categorized as etch-and-rinse and self-etch systems. When using etchand-rinse adhesive systems, the surface and subsurface mineral components of dentin are removed totally by acid etching ${ }^{[1-3]}$. When the conditioning step is followed by a priming step and subsequent application of the adhesive resin, they are recognized and available as three-step adhesive systems. On the other hand when the primer and adhesive resin are combined into one application and presented as two-step procedures that reduce the number of clinical steps ${ }^{[1]}$.

In this single bottle there is a mixture of hydrophilic, hydrophobic monomers and solvent $t^{[3-5]}$. The presence of solvents favors the penetration of monomers into the collagen network and contributes to removing water ${ }^{[3]}$. Vapor pressure is an important feature to ensure good solvent evaporation after applying the adhesive on dental tissue ${ }^{[6,7]}$, as this is related to the evaporation rate of the solvent mixture ${ }^{[7]}$. The residual solvent dispersed within the matrix monomers may difficult the polymerization and reduce degree of conversion of resin materials and thus compromise the mechanical property of the material ${ }^{[8]}$. Some studies have demonstrated that the physical properties of the adhesive resin may have a profound influence on the resin-dentin bond strengths. Low mechanical property values can compromise the bond strength of the adhesive system ${ }^{[8-12]}$. Another way, presence of acid monomers may influence on the bondig to dentin and the mechanical properties of adhesive systems ${ }^{[9,10]}$. One of the keys of success with adhesives is the chemical bonding capability of their functional monomers to hydroxyapatite (HAp).

Therefore, it is essential for clinicians to know the mechanical behavior of some adhesive systems on the market to enable them to perform successful restorations. Some studies have suggested that laboratory-screening tests continue to be indispensable in providing data to predict clinical effectiveness of dental products ${ }^{[13,14]}$.

Therefore, the aim of this study was to compare several properties of three two-step etch-and-rinse adhesives available on the market; among these, the microtensile bond strengths ( $\mu$ TBS), degree of conversion, modulus of elasticity and ultramicrohardness. The null hypothesis tested was that would be no difference in the mechanical-physical properties of the adhesive systems evaluated. 


\section{Materials and Methods}

\subsection{Microtensile bond strength}

After extraction, fifteen teeth were cleaned and stored in distilled water until used for the study. The adhesive systems used were Ambar (FGM, Joinville, SC, Brazil), Optibond (Kerr, Orange, CA, USA) and Magic Bond (Vigodent, Rio de Janeiro, RJ, Brazil), details of the composition of materials are described in Table 1. The teeth were divided into groups according the adhesive system used $(n=5)$. Occlusal enamel of each tooth was removed, using a diamond disc (Isomet 1000, Buehler, Lake Bluff, Illinois, USA) under constant water-cooling. The occlusal surface was abraded with $\mathrm{SiC}$ paper \#320 under water irrigation on a polishing machine (Aropol-E, Arotec, Cotia, SP, Brazil) to expose middle-depth dentin. A standardized smear layer was then created with $\mathrm{SiC}$ paper \#600, under continuous irrigation for $60 \mathrm{~s}$. All adhesives were applied in a controlled environment using the bonding protocols summarized in Table 1 .

Resin composite build-ups (Opallis A2, FGM, Joinville, SC, Brazil) were placed on the bonded surfaces (three increments for $1.5 \mathrm{~mm}$ each) that were individually light-activated for 40s each (Optilux 501, Kerr, Orange, CA, USA) at $600 \mathrm{~mW} / \mathrm{cm}^{2}$. After storage in distilled water at $37^{\circ} \mathrm{C}$ for $24 \mathrm{~h}$, the specimens were sectioned in both " $x$ " and " $y$ " directions, perpendicular to the adhesive/tooth interface using a water-cooled diamond saw (Isomet 1000, Buehler, Lake Bluff, Illinois, USA) to obtain rectangular beams. The number of prematurely debonded beams (PDS, specimens that failed prematurely during preparation and handling) per tooth was recorded. After $24 \mathrm{hrs}$ the specimens were tested.

Before testing, the cross-sectional area of each stick was measured with the digital caliper to the nearest $0.01 \mathrm{~mm}$ and recorded to calculate the $\mu$ TBS (Absolute Digimatic, Mitutoyo; Tokyo, Japan). The average cross-sectional area of specimens ranged from 0.79 to $0.82 \mathrm{~mm}^{2}$. Each stick was fixed with cyanocrylate glue (Pegamil Bond Gel, Buenos Aires, Argentina) and tested under tension at a crosshead speed of $1.0 \mathrm{~mm} /$ minute using an Instron testing machine (Instron 3342, Canton, MA, USA) equipped with a load cell of $500 \mathrm{~N}$.

The fractured surface of each test specimen was evaluated under a stereoscopic microscope (Kozo Optical and Electronical Instrumental, Nanjing, Jiangsu, China) at 40x magnification and classified as cohesive (failure exclusively within substrate or resin composite) and adhesive/mixed (failure at resin/substrate interface or mixed with partially cohesive failure of the neighboring substrates).

All values obtained from each tooth were averaged for statistical purposes. For each bonding substrate, the bond strength values were subjected to One-way repeated measures ANOVA and the Tukey test for comparisons $(\alpha=0.05)$.

\subsection{Degree of conversion analysis}

The DC was analyzed by FTIR spectrometer (IRPrestige-21, Shimadzu Corporation, Kyoto, Japan) equipped with an attenuated total reflectance crystal (ATR-MIRacleSingle Reflection Horizontal, Pike Technologies, Inc. Madison, WI, USA). The absorption spectra of each uncured adhesive were obtained by placing two drops of each adhesive solution directly onto the surface of the ATR diamond crystal. The absorption spectra of each polymerized adhesive specimen were obtained by dispensing two drops of the tested adhesive on an individual acetate strip and this was subsequently light-cured. After polymerization, the flat cured surface of the adhesive was firmly placed against the ATR crystal to collect the spectra. FTIR readouts were made at $22 \pm 1{ }^{\circ} \mathrm{C}$ with $50 \%$ relative humidity.

For the adhesive systems containing aromatic vinyl bonds of bisphenol and aliphatic bonds of the methacrylate functional group, the DC measurements were made with the relative intensity of the aromatic component band with the main peak around $1608 \mathrm{~cm}^{-1}$, relative to the band with aliphatic carbon-to-carbon double-bond absorbance main peak around $1638 \mathrm{~cm}^{-1}$, which changes with the polymerization of the composite (Figure 1) ${ }^{[15]}$. Thus, for the adhesive systems Ambar, Optibond and Magic Bond the absorption spectra were obtained from the region between $1650 \mathrm{~cm}^{-1}$ and $1595 \mathrm{~cm}^{-1}$ with 30 scans at a resolution of $4 \mathrm{~cm}^{-1}$.

The DC (\%) was calculated using the following equation: DC $(\%)=100 \times[1-(\mathrm{R} \text {-cured/R- uncured })]^{[16]}$, where $\mathrm{R}$ represented the ratio between the absorbance peak around $1638 \mathrm{~cm}^{-1}$ and $1608 \mathrm{~cm}^{-1}$. The data were analyzed by one-way analysis of variance (ANOVA) and post hoc Tukey tests $(\alpha=0.05)$.

\subsection{Ultramicrohardness and modulus of elasticity}

Six teeth were cut and 12 halves of tooth fragments were obtained. These fragments were distributed into groups among adhesives system used $(n=4)$. These halves were restored in the same way as described for the microtensile bond strength test. Crowns fragments were embedded in

Table 1. Composition, manufacturer, lot number and mode of application of adhesive systems tested in this study.

\begin{tabular}{|c|c|c|}
\hline Adhesive Systems & Composition & Application Mode \\
\hline $\begin{array}{l}\text { Ambar } \\
{[\mathrm{ABA}, \mathrm{FGM}]} \\
10311\end{array}$ & $\begin{array}{l}\text { UDMA, HEMA, acidic methacrylate monomers, 10-MDP, } \\
\text { methacrylate hydrophilic monomers, silanized silicon } \\
\text { dioxide, camphorquinone, 4-EDAMB, ethanol. }\end{array}$ & $\begin{array}{l}\text { (1): acid-etch }(15 \mathrm{~s}) \\
\text { (2): rinse }(15 \mathrm{~s}) \\
\text { (3): air-dry at } 20 \mathrm{~cm} \text { distance }(30 \mathrm{~s})\end{array}$ \\
\hline $\begin{array}{l}\text { Optibond S } \\
\text { [OPB, KERR] } \\
3462530\end{array}$ & $\begin{array}{l}\text { BIS-GMA, HEMA, GDM, GPDM, ethanol, silica, barium } \\
\text { glass, camphorquinone. Approximately } 15 \% \text { of filler } \\
\text { weight to } 0.4 \text { microns. }\end{array}$ & $\begin{array}{l}\text { (4): dentin rewetted with water } \\
(5): 1^{\text {st }} \text { one coat of adhesive under agitation }(10 \mathrm{~s}) \\
(6) \text { : air-dry }(10 \mathrm{~s} / 20 \mathrm{~cm})\end{array}$ \\
\hline $\begin{array}{l}\text { Magic Bond DE } \\
{[\mathrm{MGB}, \text { VIGODENT] }} \\
012 / 11\end{array}$ & $\begin{array}{l}\text { HEMA, dimethacrylates, neopentyl fluoride, acrylate } \\
\text { fluoride, adhesive monomer (MEP), highly dispersed } \\
\text { silicon dioxide, photoinitiators and stabilizers in an } \\
\text { alcoholic solution }\end{array}$ & $\begin{array}{l}\text { (7): 2nd coat of adhesive under agitation }(10 \mathrm{~s}) \\
\text { (8): air-dry }(10 \mathrm{~s} / 20 \mathrm{~cm}) \\
\text { (9): light-cure }\left(10 \mathrm{~s}-600 \mathrm{~mW} / \mathrm{cm}^{2}\right)\end{array}$ \\
\hline
\end{tabular}


Freitas, S. A. A., Lanza, M. D. S., Carneiro, K. K., Loguercio, A. D., \& Bauer, J.
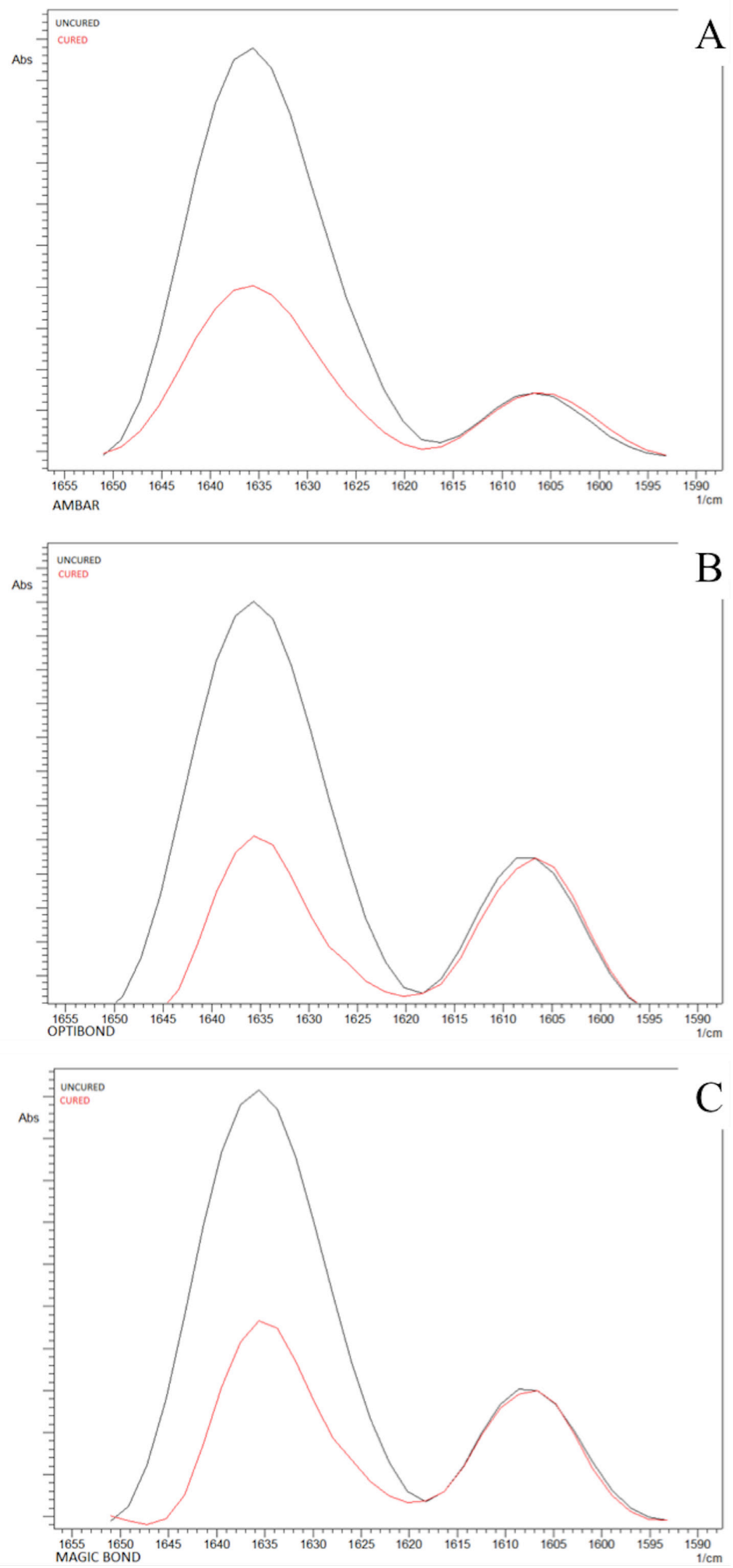

Figure 1. Fourier transform infrared spectra of adhesive systems. (A) Ambar; (B) Optibond; (C) Magic Bond, $1638 \mathrm{~cm}^{-1}=\mathrm{absorbance}$ intensity for aliphatic carbon-carbon double bonds, $1608 \mathrm{~cm}^{-1}=$ internal reference for aromatic carbon-carbon double bonds. 
transparent acrylic resin (Orthodontic Resin, Dentsply Caulk, Milford, DE, USA) and flattened in a polishing machine (Unipol 1210, MTI Corporation, CA, USA) under water-cooling with different grit silicon carbide abrasive papers and followed by a final polishing performed using diamond pastes from $1 \mu \mathrm{m}$ and lower. The modulus of elasticity and hardness across the interface were evaluated after $24 \mathrm{~h}$ of storage in distilled water at $37^{\circ} \mathrm{C}$.

The measurements were obtained using a dynamic ultra microhardness tester (DUH-211S, Shimadzu Corporation, Kyoto, Japan). The indenter used was a pyramidal-triangular shaped Berkovich indenter $\left(115^{\circ}\right)$ and the maximum force applied was $19.61 \mathrm{mN}$. Each indentation was accomplished by a load-unload step at a speed of $4.44 \mathrm{mN} / \mathrm{sec}$. The hold time at the maximum load was $7 \mathrm{sec}$ and the hold time with minimum load was $5 \mathrm{sec}$. The elastic modulus calculation for each read out was measured between of 100 and $70 \%$ of the test curve. The software associated with the DUH-211S analyzes the data, calculated and expressed the hardness and the elastic modulus values from the load-unload curve recorded. Four indentations were performed in the adhesive layer. The distance between each indentation was kept constant by adjusting the distance intervals to $10( \pm 1) \mu \mathrm{m}$.

The modulus of elasticity and ultramicrohardness data were analyzed by one-way analysis of variance (ANOVA) and post hoc Tukey tests $(\alpha=0.05)$.

\section{Results}

\subsection{Microtensile bond strength}

Statistical analysis was performed with SPSS Statistics for Windows version 20 (SPSS; Chicago, IL, USA). The Shapiro-Wilk test indicated normal distribution of the data $(\mathrm{p}=0.610)$ that were analyzed by using one-way ANOVA and Tukey tests. The Tukey post hoc test showed the highest $\mu$ TBS was obtained for Ambar and Optibond with no statistical difference $(p>0.005)$. The lowest $\mu$ TBS values were found for Magic Bond with statistical difference $(p=0.0034)$ (Table 2). The failure mode distributions for all adhesive system tested are depicted in Figure 2. The predominant failure mode was adhesive/mixed between the adhesive and dentin.

\subsection{Degree of conversion}

The DC was significantly influenced for some of the adhesive systems analyzed $(p<0.005)$. The Tukey post hoc test showed the highest DC was obtained for Ambar and Optibond with no statistical difference $(p>0.005)$. The lowest DC values were found for Magic Bond with statistical difference $(p=0.0098)$ (Table 2).

\subsection{Ultramicrohardness and Modulus of elasticity}

The ultramicrohardness and modulus of elasticity were significantly influenced for some of the adhesive systems analyzed $(\mathrm{p}<0.005)$. The Tukey post hoc test showed the

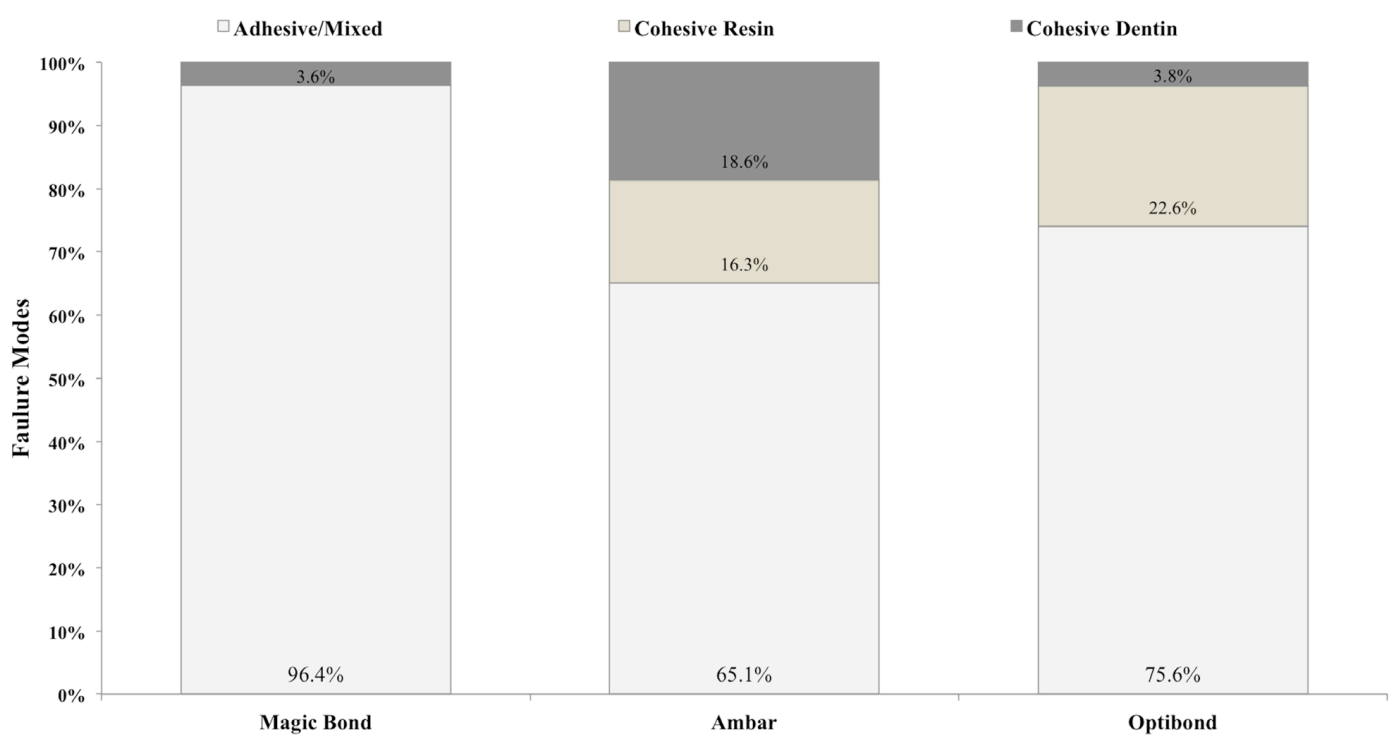

Figure 2. Incidence of failure modes (\%) analyzed by stereomicroscopy of the Magic Bond, Ambar and Optibond systems.

Table 2. Mean values of microtensile bond strength ( $\mu$ TBS), degree of conversion (\%), ultramicrohardness and modulus of elasticity (GPa) of adhesive systems used*.

\begin{tabular}{ccccc}
\hline Materials & $\boldsymbol{\mu}$ TBS (MPa) & Degree Conversion (\%) & Ultramicrohardness & Modulus (GPa) \\
\hline Ambar & $60.4 \pm 8.7 \mathrm{a}$ & $53.9 \pm 4.5 \mathrm{a}$ & $21.0 \pm 1.3 \mathrm{~b}$ & $0.69 \pm 0.09 \mathrm{~b}$ \\
Optibond & $59.7 \pm 16.1 \mathrm{a}$ & $58.6 \pm 0.9 \mathrm{a}$ & $28.7 \pm 1.3 \mathrm{a}$ & $0.87 \pm 0.008 \mathrm{a}$ \\
Magic Bond & $27.8 \pm 14.2 \mathrm{~b}$ & $44.5 \pm 9.4 \mathrm{~b}$ & $23.4 \pm 1.6 \mathrm{~b}$ \\
\hline
\end{tabular}

*Different letters in the vertical mean statistical difference. 
highest ultramicrohardness and modulus of elasticity were obtained for Optibond with statistical difference from Ambar and Magic Bond ( $p=0.0003$ and $p=0.002$ respectively) (Table 2).

\section{Discussion}

The null hypothesis tested in this study was rejected because the adhesives tested show different mechanicalphysical properties. Microtensile bond strength is the property that suggests that the quality and quantity of monomer infiltrated into the demineralized substrate and high bond strength values can be an excellent indicator of the clinical behavior of the material ${ }^{[17]}$.

The high bond strength values obtained with the Optibond adhesive system may be related to the presence of the monomer GPDM in its composition. The greater capability of the GPDM monomer could be speculated to be due two factors: (1) the phosphate group was responsible for acid etching on dentin and (2) development of a chemical bond with the mineral component ${ }^{[18-21]}$. On the other hand, it has two methacrylate functional groups for copolymerization with other methacrylate monomers to provide increased crosslinking density and enhanced mechanical strength for the polymerized adhesive ${ }^{[14]}$. Perhaps for this reason this adhesive system showed a high degree of conversion, ultramicrohardness and modulus of elasticity.

In this same way, the high microtensile bond strength values for Ambar can be explained by the presence of multifunctional monomer 10-MDP. This monomer contains a polymerizable methyl-methacrylate group and a phosphate group responsible for ionic interaction with calcium ${ }^{[19,22]}$, 10-methacryloyloxydecyl dihydrogenphosphate (MDP) has demonstrated a very effective and durable bond to dentine, due to the low solubility of the calcium salt that forms on the hydroxyapatite surface.

Moreover, the Magic Bond adhesive system showed the lowest bond strength values. Fontes et al. ${ }^{[23]}$ found poor results with this material, and most of the specimens obtained from this material in the present study were lost during the cutting procedure. These same authors explained that this low microtensile bond strength obtained by the Magic Bond system is due to lack of accurate information about the evaporation of the solvent and water. In the present study, the authors standardized the application mode for all adhesive systems and the type of solvent (ethanol).

While the adhesive systems Ambar and Optibond have monomers with the ability to bind to the hydroxyapatite component of dentin substrate, the adhesive MGB presents a generics monomers and dimethacrylate monomer (MEP). Perhaps, the monomers present in Magic Bond adhesive did not have the ability to form a chemical bond with the dental substrate.

Several studies have endeavored to correlate the mechanical property values with the bond strength results ${ }^{[17,24-26]}$. Hasegawa et al. ${ }^{[24]}$ reported that tensile bond strength values to dentin significantly correlated with the values of mechanical properties of the resin composites such as tensile strength, flexural strength and modulus of the adhesive.
In the present study the Magic Bond adhesive system presented elastic modulus and ultramicrohardness values similar to those obtained with the adhesive system Ambar. The importance of the mechanical properties of the material with regard to bond strength is due to the hybridization/ infiltration of the adhesive system into the collagen network and dentinal tubules, thereby creating greater micromechanical interlocking with this tissue after light polymerization.

An adhesive system with a high mechanical strength could also resist the stresses generated during a $\mu$ TBS test and thus present a high bonding to dentin ${ }^{[13]}$. Perhaps the high modulus of elasticity and hardness of the adhesive system was not sufficient to ensure high bonding strength to dentin ${ }^{[17]}$. According to the results obtained in this study, it is clear that the acid monomers with a high affinity for the mineral must be present in the adhesive system to ensure chemical interaction with the substrate. However, an adhesive system with low mechanical properties may compromise the resin/dentin bond interface ${ }^{[25,26]}$.

The adhesive systems that presented a high degree of conversion also showed good performance in the $\mu$ TBS test. Conversion of monomer into polymer plays an important role in successful dentin bonding ${ }^{[27]}$. A low degree conversion of dental adhesives is associated with low bond strength values, mechanical properties and high permeability ${ }^{[28-30]}$.

Hass et al. ${ }^{[31]}$ was recently able to demonstrate that there is a strong correlation between the degree of conversion of adhesive systems and $\mu$ TBS values. Another way, a good performance of an adhesive system to bond with the dentin depends on countless factors. However, it seems clear that a high degree of conversion ${ }^{[32]}$ and the presence of monomers with an affinity for hydroxyapatite ${ }^{[33,34]}$ it is desirable for a good bonding system.

\section{Conclusions}

The Optibond adhesive system was capable that show a high degree of conversion, ultramicrohardness, modulos of elasticity and resin-dentin microtensile bond strength.

\section{Acknowledgements}

This study was supported by the Foundation for the Support of Scientific and Technological Research of Maranhão (FAPEMA - BEPP-03730/13).

\section{References}

1. Pashley, D. H., Tay, F. R., Breschi, L., Tjäderhane, L., Carvalho, R. M., Carrilho, M., \& Tezvergil-Mutluay, A. (2011). State of the art etch-and-rinse adhesives. Dental Materials, 27(1), 1-16. PMid:21112620. http://dx.doi.org/10.1016/j.dental.2010.10.016.

2. Sezinando,A. (2014). Looking for the ideal adhesive-A review. Revista Portuguesa de Estomatologia Medicina Dental Cirurgia Maxilofacial, 55(4), 194-206. http://dx.doi.org/10.1016/j. rpemd.2014.07.004.

3. Silva e Souza, M. H., Jr., Carneiro, K. G. K., Lobato, M. F., Silva e Souza, P. A. R., \& Góes, M. F. (2010). Adhesive systems: important aspects related to their composition and clinical use. Journal of Applied Oral Science, 18(3), 207-214. PMid:20856995. http://dx.doi.org/10.1590/S1678-77572010000300002. 
4. Carvalho, R. M., Mendonca, J. S., Santiago, S. L., Silveira, R. R., Garcia, F. C., Tay, F. R., \& Pashley, D. H. (2003). Effects of HEMA/solvent combinations on bond strength to dentin. Journal of Dental Research, 82(8), 597-601. PMid:12885842. http://dx.doi.org/10.1177/154405910308200805.

5. De Munck, J., Van Landuyt, K., Peumans, M., Poitevin, A., Lambrechts, P., Braem, M., \& Van Meerbeek, B. (2005). A critical review of the durability adhesion to tooth tissue: methods and results. Journal of Dental Research, 84(2), 118 132. PMid:15668328. http://dx.doi.org/10.1177/1544059105 08400204.

6. Abate, P. F., Rodriguez, V. I., \& Macchi, R. L. (2000). Evaporation of solvent in one-bottle adhesives. Journal of Dentistry, 28(6), 437-440. PMid:10856809. http://dx.doi. org/10.1016/S0300-5712(00)00018-X.

7. Ikeda, T., De Munck, J., Shirai, K., Hikita, K., Inoue, S., Sano, H., Lambrechts, P., \& Van Meerbeek, B. (2005). Effect of evaporation of primer components on ultimate tensile strength of primer-adhesive mixture. Dental Materials, 21(11), 1051-1058. PMid:16140370. http://dx.doi.org/10.1016/j. dental.2005.03.010.

8. Reis, A., Carrilho, M., Breschi, L., \& Loguercio, A. D. (2013). Overview of clinical alternatives to minimize the degradation of the resin-dentin bonds. Operative Dentistry, 38(4), E103-E127. PMid:23527523. http://dx.doi.org/10.2341/12-258-LIT.

9. Paul, S. J., Leach, M., Rueggeberg, F. A., \& Pashley, D. H. (1999). Effect of water content on the physical properties of model dentine primer and bonding resins. Journal of Dentistry, 27(3), 209-214. PMid:10079627. http://dx.doi.org/10.1016/ S0300-5712(98)00042-6.

10. Ito, S., Hashimoto, M., Wadgaonkar, B., Svizero, N., Carvalho, R. M., Yiu, C., Rueggeberg, F. A., Foulger, S., Saito, T., Nishitani, Y., Yoshiyama, M., Tay, F. R., \& Pashley, D. H. (2005). Effects of resin hydrophilicity on water sorption and changes in modulus of elasticity. Biomaterials, 26(33), 6449-6459. PMid:15949841. http://dx.doi.org/10.1016/j. biomaterials.2005.04.052.

11. Yiu, C. K., Pashley, E. L., Hiraishi, N., King, N. M., Goracci, C., Ferrari, M., Carvalho, R. M., Pashley, D. H., \& Tay, F. R. (2005). Solvent and water retention in dental adhesive blends after evaporation. Biomaterials, 26(34), 6863-6872. PMid:15964621. http://dx.doi.org/10.1016/j.biomaterials.2005.05.011.

12. Cadenaro, M., Antoniolli, F., Sauro, S., Tay, F. R., Di Lenarda, R., Prati, C., Biasotto, M., Contardo, L., \& Breschi, L. (2005). Degree of conversion and permeability of dental adhesives. European Journal of Oral Sciences, 113(6), 525-530. PMid:16324144. http://dx.doi.org/10.1111/j.1600-0722.2005.00251.X.

13. Van Meerbeek, B., De Munck, J., Yoshida, Y., Inoue, S., Vargas, M., Vijay, P., Van Landuyt, K., Lambrechts, P., \& Vanherle, G. (2003). Buonocore memorial lecture. Adhesion to enamel and dentin: current status and future challenges. Operative Dentistry, 28(3), 215-235. http://dx.doi.org/10.2341/15592863-28-3-1. PMid:12760693.

14. Loguercio, A. D., Luque-Martinez, I., Muñoz, M. A., Szesz, A. L., Cuadros-Sánchez, J., \& Reis, A. (2014). A comprehensive laboratory screening of three-step etch-and-rinse adhesives. Operative Dentistry, 39(6), 652-662. PMid:24720263. http:// dx.doi.org/10.2341/13-236.

15. Borges, B. C. D., Souza-Junior, E. J., Brandt, W. C., Loguercio, A. D., Montes, M. A. J. R., Puppin-Rontani, R. M., \& Sinhoreti, M. A. C. (2012). Degree of conversion of simplified contemporary adhesive systems as influenced by extended air-activated or passive solvent volatilization modes. Operative Dentistry, 37(3), 246-252. PMid:22313268. http:// dx.doi.org/10.2341/11-248-L.
16. Pianelli, C., Devaux, J., Bebelman, S., \& Leloup, G. (1999). The Micro-Raman spectroscopy, a useful tool to determine the degree of conversion of light-ativated composites resins. Journal of Biomedical Materials Research, 48(5), 675-681. PMid:10490681. http://dx.doi.org/10.1002/(SICI)10974636(1999)48:5<675::AID-JBM11>3.0.CO;2-P.

17. Takahashi, A., Sato, Y., Uno, S., Pereira, P. N., \& Sano, H. (2002). Effects of mechanical properties of adhesive resins on bond strength to dentin. Dental Materials, 18(3), 263-268. PMid:11823019. http://dx.doi.org/10.1016/S01095641(01)00046-X.

18. Goracci, C., Margvelashvili, M., Giovannetti, A., Vichi, A., \& Ferrari, M. (2013). Shear bond strength of orthodontic brackets bonded with a new self-adhering flowable resin composite. Clinical Oral Investigations, 17(2), 609-617. PMid:22538472. http://dx.doi.org/10.1007/s00784-012-0729-x.

19. Yoshida, Y., Nagakane, K., Fukuda, R., Nakayama, Y., Okazaki, M., Shintani, H., Inoue, S., Tagawa, Y., Suzuki, K., De Munck, J., \& Van Meerbeek, B. (2004). Comparative study on adhesive performance of functional monomers. Journal of Dental Research, 83(6), 454-458. PMid:15153451. http://dx.doi.org $/ 10.1177 / 154405910408300604$.

20. Sezinando, A., Perdigão, J., \& Regalheiro, R. (2012). Dentin bond strengths of four adhesion strategies after thermal fatigue and 6-month water storage. Journal of Esthetic and Restorative Dentistry, 24(5), 345-355. PMid:23025319. http://dx.doi. org/10.1111/j.1708-8240.2012.00531.x.

21. Stona, P., Borges, G. A., Montes, M. A., Burnett, L. H., Jr., Weber, J. B., \& Spohr, A. M. (2013). Effect of polyacrylic acid on the interface and bond strength of self-adhesive resin cements to dentin. The Journal of Adhesive Dentistry, 15(3), 221-227. PMid:23560256. http://dx.doi.org/10.3290/j.jad. a29531.

22. Luque-Martinez, I. V., Perdigão, J., Muñoz, M. A., Sezinando, A., Reis, A., \& Loguercio, A. D. (2014). Effects of solvent evaporation time on immediate adhesive properties of universal adhesives to dentin. Dental Materials, 30(10), 1126-1135. PMid:25139815. http://dx.doi.org/10.1016/j.dental.2014.07.002.

23. Fontes, S. T., Cubas, G. B., Flores, J. B., Montemezzo, M. L., Pinto, M. B., \& Piva, E. (2010). Resin-dentin bond strength of 10 contemporary etch-and-rinse adhesive systems after one year of water storage. General Dentistry, 58(6), 257-261. PMid:21062710.

24. Hasegawa, T., Itoh, K., Koike, T., Yukitani, W., Hisamitsu, H., Wakumoto, S., \& Fujishima, A. (1999). Effect of mechanical properties of resin composites on the efficacy of the dentin bonding system. Operative Dentistry, 24(6), 323-330. http:// dx.doi.org/10.2341/1559-2863-24-6-1. PMid:10823080.

25. Carrilho, M. R., Carvalho, R. M., Tay, F. R., \& Pashley, D. H. (2004). Effects of storage media on mechanical properties of adhesive systems. American Journal of Dentistry, 17(2), 104-108. PMid:15151336.

26. Carrilho, M. R. O., Tay, F. R., Pashley, D. H., Tjäderhane, L., \& Carvalho, R. M. (2005). Mechanical stability of resindentin bond components. Dental Materials, 21(3), 232-241. PMid:15705430. http://dx.doi.org/10.1016/j.dental.2004.06.001.

27. Eick, J. D., Gwinnett, A. J., Pashley, D. H., \& Robinson, S. J. (1997). Current concepts on adhesion to dentin. Critical Revision of Oral Biology and Medcine, 8(3), 306-335. PMid:9260046. http://dx.doi.org/10.1177/10454411970080030501.

28. Kanehira, M., Finger, W. J., Hoffmann, M., Endo, T., \& Komatsu, M. (2006). Relationship between degree of polymerization and enamel bonding strength with self-etching adhesives. The Journal of Adhesive Dentistry, 8(4), 211-216. PMid:16958284. 
29. Wang, Y., Spencer, P., Yao, X., \& Ye, Q. (2006). Effect of coinitiator and water on the photoreactivity and photopolymerization of HEMA/camphorquinone-based reactant mixtures. Journal of Biomedical Materials Research. Part A, 78(4), 721-728. PMid:16739171. http://dx.doi.org/10.1002/ jbm.a.30733.

30. Cadenaro, M., Antoniolli, F., Codan, B., Agee, K., Tay, F. R., Dorigo, E. S., Pashley, D. H., \& Breschi, L. (2010). Influence of different initiators on the degree of conversion of experimental adhesive blends in relation to their hydrophilicity and solvent content. Dental Materials, 26(4), 288-294. PMid:20018363. http://dx.doi.org/10.1016/j.dental.2009.11.078.

31. Hass, V., Dobrovolski, M., Zander-Grande, C., Martins, G. C., Gordillo, L. A. A., Accorinte, M. L. R., Gomes, O. M. M., Loguercio, A. D., \& Reis, A. (2013). Correlation between degree of conversion, resin-dentin bond strength and nanoleakage of simplified etch-and-rinse adhesives. Dental Materials, 29(9), 921-928. PMid:23830512. http://dx.doi.org/10.1016/j. dental.2013.05.001.
32. Ferracane, J. L. (2006). Hygroscopic and hydrolytic effects in dental polymer networks. Dental Materials, 22(3), 211-222. PMid:16087225. http://dx.doi.org/10.1016/j.dental.2005.05.005.

33. Van Landuyt, K. L., Yoshida, Y., Hirata, I., Snauwaert, J., De Munck, J., Okazaki, M., Suzuki, K., Lambrechts, P., \& Van Meerbeek, B. (2008). Influence of the chemical structure of functional monomers on their adhesive performance. Journal of Dental Research, 87(8), 757-761. PMid:18650548. http:// dx.doi.org/10.1177/154405910808700804.

34. Yoshihara, K., Yoshida, Y., Nagaoka, N., Fukegawa, D., Hayakawa, S., Mine, A., Nakamura, M., Minagi, S., Osaka, A., Suzuki, K., \& Van Meerbeek, B. (2010). Nano-controlled molecular interaction at adhesive interfaces for hard tissue reconstruction. Acta Biomaterialia, 6(9), 3573-3582. PMid:20346420. http:// dx.doi.org/10.1016/j.actbio.2010.03.024.

Received: Mar. 02, 2016

Revised: June 27, 2016

Accepted: Aug. 28, 2016 